\title{
Situation of human rights in Afghanistan
}

\section{Note by the Secretary-General ${ }^{* *}$}

The Secretary-General has the honour to transmit to the members of the General Assembly a brief interim report on the situation of human rights in Afghanistan prepared by Kamal Hossain, Special Rapporteur of the Commission on Human Rights, in accordance with Commission on Human Rights resolution 2000/18 of 18 April 2000 and Economic and Social Council decision 2000/251 of 28 July 2000 .

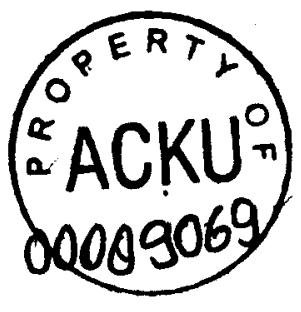

* A/55/150.

** In accordance with General Assembly resolution 54/248, sect. C, para. 1, this report is being submitted on 30 August 2000 so as to take into account the Economic and Social Council mandate and as much updated information as possible. 


\section{Interim report of the Special Rapporteur of the Commission on Human Rights on the situation of human rights in Afghanistan}

\section{Contents}

\begin{tabular}{|c|c|c|c|}
\hline & & Paragraphs & Pag \\
\hline I. & Introduction . & $1-8$ & \\
\hline II. & Developments aimed at promoting the peace process (April-July 2000) & $9-20$ & \\
\hline III. & Resumption of conflict (June-August 2000) & $21-26$ & \\
\hline IV. & $\begin{array}{l}\text { Impact of continuing conflict, drought and displacement on the humanitarian } \\
\text { situation } \ldots \ldots \ldots \ldots \ldots \ldots \ldots \ldots \ldots \ldots \ldots \ldots \ldots \ldots \ldots \ldots \ldots \ldots \ldots \ldots \ldots\end{array}$ & $27-37$ & \\
\hline V. & Human rights situation (June-August 2000 ) & $38-57$ & \\
\hline VI. & Concluding observations. & $58-64$ & \\
\hline
\end{tabular}

Letter dated 26 April 2000 from the Special Rapporteur of the Commission on Human Rights on the situation of human rights in Afghanistan addressed to the President of the Islamic State of Afghanistan 


\section{Introduction}

1. This is the fourth report of the Special Rapporteur of the Commission on Human Rights on the situation of human rights in Afghanistan. He presented his first report (E/CN.4/1999/40) to the Commission on Human Rights at its fifty-fifth session in March 1999, a second, interim report $(\mathrm{A} / 54 / 422)$ to the General Assembly at its fifty-fourth session in November 1999 and a third report (E/CN.4/2000/33) to the Commission on Human Rights at its fifty-sixth session in March 2000 .

2. The first report was made following visits to Kabul and to Islamabad and Peshawar, where Afghan refugee groups were interviewed in March 1999. The interim report to the General Assembly was preceded by a visit to Quetta and Kandahar in May 1999 and to Kabul and Islamabad in September 1999, following the receipt of allegations of serious human rights violations which were occurring as a result of resumption of conflict in the central highlands in Afghanistan, in particular in Bamyan in May, and in the Shamali Plains north of Kabul in July 1999. The Special Rapporteur's visits were aimed at gathering first-hand information. In May, he interviewed refugees, including women and children recently arrived from Hazarajat. In Kabul, he interviewed persons who had been forcibly displaced from the Shamali Plains in July 1999. The visit to Kabul was undertaken together with Radhika Coomaraswamy, the Special Rapporteur of the Commission on Human Rights, who has dealt with the issues related to women's rights in some detail in a subsequent, separate report (E/CN.4/2000/68/Add.4).

3. Prior to finalizing the present report, the Special Rapporteur travelled to the Islamic Republic of Iran where he visited Tehran and Mashhad. He visited the voluntary repatriation centre set up by the Office of the United Nations High Commissioner for Refugees (UNHCR) at Chahar Sheshmeh and the screening centre in Mashhad. The Special Rapporteur was able to interview refugees of various ages and ethnic groups and, in particular women, mostly widows, who were heads of their families. He spent one half day in the Golshahr neighbourhood of Mashhad, where there is a large concentration of Afghan refugees. The Special Rapporteur visited the library partly supported by UNHCR, where he met a number of male and female students, as well as a skills development centre at which teenage girls were given training in the use of computers and other skills. An establishment which specially demonstrated the tragic consequences of prolonged armed conflict in Afghanistan was a kindergarten school run for war orphans, most of them from the central highlands of Hazarajat.

4. The Special Rapporteur met in Tehran highranking governmental officials, including Mohammad Ebrahim Taherian, Chief of Afghanistan Headquarters, Ministry of Foreign Affairs; Hojatoleslam Ebrahimi, Adviser to the Minister of the Interior and DirectorGeneral of the Bureau for Aliens and Foreign Immigrants (BAFIA); Mohsen Aminzadeh, ViceMinister for West Asia, Ministry of Foreign Affairs; and M. Daneshyazdi, Director-General, Social and International Affairs, Ministry of Foreign Affairs. In Mashhad, he met Ali-Akhbari, Adviser to the Governor-General of Khorassan province on Afghan Affairs; and M. Olama, Director-General, BAFIA, Khorassan.

5. The Special Rapporteur would like to record his appreciation for the assistance extended to him by the Office of the United Nations Resident Coordinator in the Islamic Republic of Iran, and the Chief of Mission, UNHCR, and to the members of their staff. He would also like to express his gratitude to the Office of the United Nations Special Mission to Afghanistan (UNSMA) in Tehran and to the representatives in the Islamic Republic of Iran of the United Nations International Drug Control Programme, the World Food Programme (WFP), the United Nations Children's Fund (UNICEF), the United Nations Population Fund (UNFPA), the United Nations Educational, Scientific and Cultural Organization (UNESCO), the World Health Organization (WHO) and the International Organization for Migration (IOM).

6. The Special Rapporteur has always been mindful that, in accordance with Economic and Social Council resolution 1984/37 of 24 May 1984, his basic mandate is to examine the human rights situation in Afghanistan, with a view to formulating proposals which could contribute to ensuring full protection of the human rights of all residents of the country, before, during and after the withdrawal of all foreign forces. It has been his constant endeavour to obtain direct testimony with regard to human rights violations and violations of international humanitarian law. That testimony has been gathered both through visits to Kabul and Kandahar and from refugees in Peshawar, 
Quetta, Islamabad, Tehran, Mashhad and other locations. The thrust of his previous two reports has been to provide an overall assessment and to identify the root causes of what is generally characterized as an appalling human rights situation and to make recommendations on how effective steps may be taken to improve it. The existing situation is described in the most recent report of the Secretary-General (A/54/918$\mathrm{S} / 2000 / 581$ ) in the following terms:

"The situation of the Afghan people remains deplorable. Four years after the takeover of Kabul by the Taliban, visitors compare the city to a bombed-out city a few years after the end of the Second World War, except that no reconstruction is in sight and its people have little hope for improvement. There is a growing process of pauperization throughout Afghanistan, exacerbated by the most severe drought in 30 years. More than 20 years after the invasion of Afghanistan in 1979 and the billions of dollars expended to feed successive war efforts, Afghanistan remains in a state of acute crisis its resources depleted, its intelligentsia in exile, its people disfranchised, its traditional political structures shattered and its human development indices among the lowest in the world."

7. The severe drought which has affected much of Afghanistan is reported to be destroying the livelihood of over one million people. Some 80 per cent of the livestock of the Kuchi nomads is reportedly dead. The Argun water reservoir which supplied water to 500,000 farmers and the urban inhabitants of Kandahar for the past 15 years has run dry, as have reportedly 8 of the 10 rivers in the region. All of these events, according to an international assessment, have resulted in a humanitarian and environmental disaster in Afghanistan. The need for extended humanitarian assistance for the survival of those affected by drought cannot be overemphasised. The impact of the continuing conflict and the drought is described in section IV below.

8. In the current year, extensive policy reviews have been carried out in the United Nations, in the Organization of the Islamic Conference (OIC), in regional meetings and in various international meetings, including meetings of representatives of neighbouring countries. There is growing recognition that a clear identification of strategic goals is necessary. It is considered that there is a need for a resolute and concerted effort to implement effective measures to bring to an end the 20-year-long conflict which has caused massive destruction and inflicted enormous suffering on the people of this unfortunate country. There is also the need for the peace process to move forward and for a phased transition to take place for the establishment of a multi-ethnic, broad-based, truly representative government. Only such a government could set about rebuilding not only the physical infrastructure but also the institutions of governance within a constitutional and legal framework that conforms to the human rights standards contained in the international instruments, to which Afghanistan continues to be a party.

\section{Developments aimed at promoting the peace process (April-July 2000)}

\section{Personal Representative of the Secretary-General and Head of the United Nations Special Mission to Afghanistan}

9. The Personal Representative of the SecretaryGeneral and Head of UNSMA visited Kandahar and Kabul to hold discussions with Taliban leaders and also travelled to Dushanbe on 19 April to talk with the leaders of the United Front. The Personal Representative conveyed to all parties the deep concern of the Security Council, expressed in the Presidential statement of 7 April 2000 (S/PRST/2000/12), made on behalf of the Security Council, regarding reports that both parties to the conflict were preparing for renewed large-scale fighting, and the consequences that might ensue if the concerns of the Council were not heeded. While neither side had made any commitment, both declared that any military action by their respective sides would be purely defensive in nature.

10. Other issues discussed by the Personal Representative included ideas as to how a peace process under United Nations auspices might be structured; the establishment of a broadly based, multiethnic, fully representative government and the role in it of Mullah Mohammad Omar; the relations of the two sides with outside powers, including Pakistan, the Islamic Republic of Iran, the Central Asian republics, the Russian Federation and the United States of America; the demand by the Security Council in 
paragraph 2 of its resolution 1267 (1999) of 15 October 1999 that the Taliban turn over Osama bin Laden; the broader issue of terrorism and, more concretely, the alleged existence of training camps for foreign militants in areas controlled by the Taliban; the continued interference of third countries in the affairs of Afghanistan and the presence of foreigners in the fighting; the production of and trade in narcotics; the impact of the escape of Ismail Khan from a Kandahar prison; relations among the various United Front leaders, including Ahmad Shah Massoud, Abdul Rashid Dostum and Abdul Malik, and the participation of the two warring parties in the Loya Jirgah, or traditional Afghan Grand Assembly, that may be convened.

11. The Personal Representative appealed to both parties, as had the Special Rapporteur in his letter dated 26 April 2000 (see annex), not to target civilian populations in the event of fighting, and discussed issues relating to the release of political prisoners and prisoners of war, allegations of serious human rights violations, reports of the dismissal of the female civil servants from government services and gender issues.

12. The Civil Affairs Unit of UNSMA, which has among its aims the improvement of the human rights situation by preventing further abuse through persuasion rather than denunciation, has been able to deploy civil affairs officers in Herat, Kabul, Kandahar and Jalalabad. Permission to open an office in Mazar-eSharif has so far been denied.

\section{Organization of the Islamic Conference: Jeddah talks (March/May 2000)}

13. Pursuant to a diplomatic initiative launched in February 2000 by President Sayyed Mohammad Khatami of the Islamic Republic of Iran in his capacity as Chairman of OIC, talks were held among the warring parties of Afghanistan, with the Permanent Representative attending as an observer. The talks conducted under the Chairmanship of Iranian Deputy Foreign Minister Zarif resulted in an agreement to hold a second round of talks, which was held at Jeddah from 8 to 10 May. These talks led to an agreement for a comprehensive exchange of prisoners of war between the two sides, to be conducted through the International Committee of the Red Cross (ICRC). A special team, consisting of representatives from the Islamic Republic of Iran, Pakistan, UNSMA and the Secretary-General, was set up to facilitate the implementation of the agreement. The two sides also agreed to respect their existing commitment not to target the civilian populations and to allow the unimpeded passage of humanitarian convoys to the civilian population on both sides of the front lines.

14. Around 21 June, the opposing forces in Afghanistan were to inspect each other's jails in preparation for exchange of prisoners. A six-member delegation headed by Mohammad Saleh arrived in Kabul on 21 June on behalf of United Front forces. The Taliban delegation, led by Moulvi Hamidullah, arrived in the Panjshir Valley. The United Front team was to visit jails in Kabul and Kandahar. Statistics on the number of prisoners vary. According to the United Front, the Taliban are reported to be holding 4,200 United Front loyalists, of which only between 600 and 700 are fighters captured in action. The number of Taliban prisoners in Taloqan was said to be about 700 but according to a senior Taliban official, the number would not exceed 400 . Allegations were levelled that the Taliban, in order to avoid the exchange of prisoners from Mazar-e-Sharif, Samangan and Sar-e-Pol, had summarily executed, according to one report, 89 of them and, according to another, 189. The Taliban authorities denied these allegations. This is a matter which would need to be pursued further. A United Front spokesman has stated that the list of prisoners received from the Taliban contained the names of 100 non-Afghan prisoners.

15. Lists of prisoners were reported to be under preparation and the exchange of such lists was expected to take place. The importance of the exchange of prisoners lies in the fact that it would be a major step in a process that needs to be initiated in order to establish an enduring and stable peace in Afghanistan.

\section{Loya Jirgah initiative}

16. The Loya Jirgah initiative, described in the previous report of the Special Rapporteur, was launched in April 1999 by the former King Zaher Shah from Rome, and is known as the Rome process. Those involved in that initiative sent a delegation to United Nations Headquarters and to Washington, D.C., to explain their activities and to seek support. They sent similar delegations to countries members of the 
European Union, Pakistan and Kandahar. They expect to send delegations to meet with the United Front, and to the Russian Federation and the Islamic Republic of Iran. A representative of a similar initiative arising from a meeting in Cyprus also visited New York to explain its activities.

\section{"Six plus two" Group and Group of 21}

17. A technical meeting of the "six plus two" group on drugs emanating from Afghanistan was held in Vienna from 8 to 10 May 2000 , and a meeting of their representatives was convened by the Personal Representative in Islamabad on 22 May. On 30 May, the Personal Representative convened in Islamabad a meeting of a larger group of representatives of Governments with influence in Afghanistan, known as the Group of 21 . The members of the Group of 21 , which had not met since June 1998, are China, Egypt, France, Germany, India, the Islamic Republic of Iran, Italy, Japan, Kazakhstan, Kyrgyzstan, the Netherlands, Pakistan, the Russian Federation, Saudi Arabia, Sweden, Tajikistan, Turkey, Turkmenistan, the United Kingdom of Great Britain and Northern Ireland, the United States of America and Uzbekistan, as well as OIC.

\section{International cooperation for peace within the framework of the United Nations}

18. Intensive consultations have been undertaken by the Personal Representative. Afghanistan has featured in discussions in major international and regional meetings and in meetings between the United States of America and the Russian Federation, between the Russian and Central Asian leaders, between China and the Central Asian States, between China and Pakistan, and between the Islamic Republic of Iran and Pakistan. These discussions appear to have recognized the need for a negotiated peace which could rescue Afghanistan and its long-suffering people from the ravages of conflict, economic devastation and human rights violations.

19. The current expressions of international concern and emphasis on the special responsibility of the United Nations and the international community echo some of the core elements of the Geneva Accords of
1988, which provided the framework for the withdrawal of Soviet troops in 1989. On 8 April 1988, in a statement approved during the negotiations which yielded the Geneva Accords, the Under-SecretaryGeneral for Special Political Affairs recounted that, throughout the negotiations, it had been consistently recognized that the objective of a comprehensive settlement implied the broadest support and immediate participation of all segments of the Afghan people and that this could best be ensured by a broad-based Afghan government. It was equally recognized that any questions relating to the government in Afghanistan were matters within the exclusive jurisdiction of Afghanistan and could only be decided by the Afghan people themselves. The hope was therefore expressed that all elements of the Afghan nation, living inside and outside Afghanistan, would respond to that historic opportunity. At that crucial stage, all concerned would, therefore, promote the endeavours of the Afghan people to work out arrangements for a broad-based government and would support and facilitate that process.

20. The heightened interest of the international community could be reflected in a significant enhancement of the role of the United Nations in carrying forward the peace process.

\section{Resumption of conflict (June- August 2000)}

21. Towards the middle of June 2000 , even while the opposing warring groups were preparing to exchange teams to inspect each other's jails as a step towards implementation of the agreement for the exchange of prisoners, there were reports emanating from United Front sources of an externally supported Taliban offensive on the Shamali and Kunduz fronts. These followed the Taliban attacks on Salang some weeks earlier, which had been repulsed. On 26 June, at least two persons were killed when Taliban jet fighters bombed a United Front base in the Darra-e-Souf district of Samangan province and in the Kaldaro district of Balkh province in support of ground offensives.

22. Despite warnings and pleas by the Security Council, the Secretary-General, his Personal Representative and by the Special Rapporteur, as well as the Foreign Ministers of OIC and members of the 
international community at large, fighting erupted in the Shamali Plains to the north of Kabul on Saturday, 1 July, around 3 a.m. local time. Although there were conflicting versions as to which side initiated the largescale attack, it appeared that an offensive was launched by the Taliban against United Front forces in the areas of Baghram airbase and Charikar, 50 kilometres and 64 kilometres north of Kabul, respectively. The Taliban, however, sent a letter to the Secretary-General strongly denying its responsibility for initiating the offensive. It was claimed by the Taliban that their opponents had tried to portray events as if the Taliban had attacked them. Other Taliban officials had previously stated that the United Front had provoked the confrontation on 1 July by shelling the villages of Shekar Darra and Gol Darra, 25 kilometres to the north of Kabul, as well as Darra-e-Souf and Baghlan province, the previous day.

23. The Taliban forces made initial gains on the ground, but these were reversed by the United Front. In addition to military casualties, minefields laid in the Shamali Plains are reported to have taken a toll among the Taliban ranks. The United Front announced that a large number of Taliban soldiers, as many as several hundred, were killed or wounded - a claim rejected by the Taliban. Meanwhile, air raids carried out by Taliban jet fighters reportedly claimed civilian lives in Charikar and Jabal-us Saraj on 1 July and the following day.

24. Reports were received of the apparent presence of non-Afghan fighters among the Taliban. The United Front further claimed to have captured some of the foreigners during the fighting, which resumed on 1 July. The Taliban forces were reported to have gained ground on the so-called Old Road, which links Kabul with the provincial town of Charikar, held by the United Front. The Taliban were reported to have employed aerial attacks.

25. Despite intense fighting around mid-July, the front lines appeared to have remained unchanged but both sides continued to reinforce their troops to the north of Kabul. Following war preparations in the northern areas of Afghanistan, in Kunduz province, Takhar, Baghlan, Samangan and Sar-e-Pol, the Taliban were reported to have bombed northern Afghanistan on 23 July in a fresh round of fighting, killing three civilians and wounding seven others. Around $30 \mathrm{July}$, the Taliban forces captured Nahreen town in Baghlan province, after heavy artillery fire and aerialattacks.

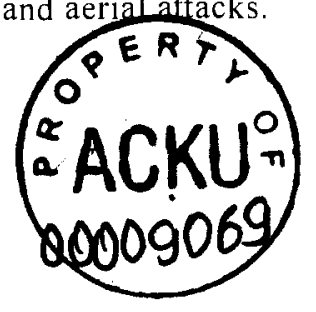

26. Around 9 August, mortar and artillery duels raged in northern Afghanistan as forces of Taliban militia battled within five miles of a key United Front stronghold before being pushed back. After 15 hours of fierce fighting, the Taliban reached the outskirts of Taloqan. A United Front official in Taloqan said that most of the city's residents had fled the relentless fighting and accompanying bombing raids by Taliban jets. Thus, significant displacement of civilian population appears to have taken place.

\section{Impact of continuing conflict, drought and displacement on the humanitarian situation}

27. The effects of one of the worst droughts continue to compound the suffering of Afghans. While the initial impact was largely on the economy, the drought began to take its toll on health and nutrition. The availability of potable water became a significant issue in urban and rural areas. Increased costs of limited food stocks in certain areas forced people to survive on famine foods. There were reports of famine-related deaths in the central highlands, where access to the affected populations remained constrained by insecurity.

28. Grave concerns were expressed by United Nations and non-governmental organizations relief partners about the adverse effects of an upsurge in fighting on an already vulnerable civilian population. The combination of war, drought and displacement continued to take a terrible toll on Afghans and their livelihoods. There was widespread fear of population displacement across the international borders.

29. The most seriously affected populations are livestock owners, especially the nomadic Kuchi population, and producers of rain-fed crops, including wheat. The mortality rate among livestock in the most affected parts of southern Afghanistan is estimated to be in the range of 50 per cent to 60 per cent. Crop loss in the majority of rain-fed areas is 90 per cent. The next chance for a normal crop from rain-fed areas will not be until 2001, since the vast majority of the cultivated land produces only one crop per year. According to the recent food and crop assessment carried out by the Food and Agriculture Organization of the United Nations (FAO) and the WFP, the food production deficit will be 2.3 million tonnes, more than double the figure for 1999 . 
30. Besides losing the thousands of head of precious livestock and hectares of wheat, Afghanistan's debilitating drought has taken a heavy toll on the fruit orchards. As the worst drought in 30 years continued to ravage crops in the south and west of the war-torn country, the cost of fruit soared, narrowing even further the nutritional options of the population. In general, wheat quality is exceptionally poor, disease levels are high and virtually none of the crop is of seed quality. In addition, the barley crop was totally lost. On 6 June 2000, the Office of the United Nations Coordinator for Afghanistan warned that, until June 2001, at least one half of the population of Afghanistan may be affected by drought. Three to four million people may be severely affected and another eight to twelve million moderately affected.

31. UNHCR was advising against the return of refugees to drought-affected areas of Afghanistan and suspended activities to facilitate and support voluntary repatriation to the most severely affected areas. Voluntary repatriation to drought-affected areas was not sustainable and could worsen conditions for the local population. Efforts were under way to ease the pressure on drought-affected refugees in Pakistan and the Islamic Republic of Iran to opt for voluntary repatriation. This reinforced the need to focus on the provision of food as well as potable and irrigation water in areas of refugee return so as to prevent renewed departure.

32. Until early August, the response of the international community to the request for US\$ 67 million for humanitarian assistance to alleviate the effects of the drought had been met only to the extent of 59 per cent of the amount requested. In the meantime, the response to the consolidated appeal for 2000 , which had until then been funded only to around 43 per cent, continued to be inadequate. The urgent need for humanitarian assistance needs to be strongly underscored. Without additional funding, even mine action operations (the critical need for which is emphasized in para. 44 below) will be reduced by 50 per cent as at 1 September 2000.

\section{Refugees}

33. One of the largest refugee movements in recent times had been generated by the over 20-year-long Afghan conflict. At present, it is estimated that there are some 1.4 million refugees in the Islamic Republic of Iran and a similar number in Pakistan, even after the voluntary repatriation from both countries of a significant number. About 100,000 refugees have opted for voluntary repatriation from Pakistan each year for the past three years, mainly to relatively peaceful areas in the eastern, central and southern regions. Pursuant to the agreement on a joint programme for the voluntary repatriation of Afghan refugees reached between UNHCR and the Government of the Islamic Republic of Iran, voluntary repatriation from that country has resumed in considerable numbers, compared to previous years. The joint programme comprises two distinct components. The first component is meant to facilitate repatriation of a voluntary nature to Afghanistan and is open to all Afghans, documented or undocumented, in the Islamic Republic of Iran. There are three voluntary repatriation centres, in Chahar Sheshmeh, Tehran and Zahedan, which Afghans wishing to return to Afghanistan approach. Those registered for voluntary repatriation after an interview to establish the voluntary nature of the return, biographical data and destination of return receive a grant of US\$20, a plastic sheet, transportation to the border, 50 kilograms of wheat, another USS 20 and transportation to provincial capitals of areas of return in Afghanistan. The second component is available to Afghans who are currently undocumented and who consider they have valid reasons not to return. They can submit claims to continued protection to joint screening teams, each comprising a representative of UNHCR and of BAFIA at six screening centres in the Islamic Republic of Iran, one of which is in Mashhad. The screening teams determine cases in which, in their view, there are genuine grounds for fear of persecution or threats to personal security and recommend the granting of refugee documents.

34. The Special Rapporteur visited Mashhad and held extensive discussions with the UNHCR representative and officials of BAFIA. He visited the voluntary repatriation centre at Chahar Sheshmeh and the screening centre in Mashhad. When speaking to those who were waiting to be interviewed at the screening centre, the Special Rapporteur was surrounded by throngs of interviewees making plaintive appeals that they should be allowed to remain in the Islamic Republic of Iran. Most of them were Tajiks or Hazaras, who are Shiites, although among them there were also Pashtuns and Farsi-speaking persons from Herat. They claimed that they had fled in the face of threats to their lives and did not wish to return to a place where they feared that they might be targets of persecution and 
discrimination, and their lives and personal security could be at risk.

35. The Special Rapporteur also visited the Golshahr locality in Mashhad, which has one of the largest concentrations of Afghan refugees. There he visited a library in which both male and female students were interviewed, and also visited a centre at which girls were receiving computer training and training in other skills. The students and trainees made very strong appeals that they should not be asked or forced to be repatriated to Afghanistan unless conditions there changed so that they could expect to continue to receive education which, according to information they had, would be denied to them in Afghanistan, as would the prospect of employment.

36. In Tehran, the Special Rapporteur met senior Iranian officials of the Ministry of Foreign Affairs and of BAFIA. He noted that the Islamic Republic of Iran had borne a substantial burden in coping with such a large refugee population for a period extending over 20 years. The Special Rapporteur pointed out that the refugees whom he had interviewed were strongly desirous of not being repatriated until conditions changed in Afghanistan, when they could feel personally secure and when women and girls did not have to live under severe legal restrictions which effectively denied to them access to employment, education and health facilities. Acute resource shortages are faced by institutions and programmes which are serving the refugee population in the Islamic Republic of Iran. A heart-rending example of this was the threat of closure faced by the kindergarten school for war orphans in Mashhad, run by Afghan women teachers who had not received salaries for six months.

37. The Iranian officials pointed out that while they had borne an enormous refugee burden over a long period, they did not receive the same level of international appreciation or international support received by other refugee-receiving countries. The Special Rapporteur indicated that he would record the views expressed by the Iranian officials in his report and would emphasize the need for substantial enhancement of international support for the refugees who were living in the country. He also pointed out that, since the screen programme under the joint agreement was to end in early October, it would not be possible for the programme to cover all of the refugees whose cases were to be processed and that it would expose them to considerable hardship and danger if they were to face the risk of large-scale forcible repatriation after the mid-October deadline. Having regard to humanitarian considerations and the human rights of the refugees, he appealed to the Government that it consider extending the deadline for repatriation and in any event not deport refugees who had not expressed the desire to return voluntarily because of a fear of persecution or a threat to their personal security and, in the case of women, because they would be denied access to employment, education and health facilities. It was emphasized that only when there was a significant improvement in the human rights situation in Afghanistan could a significant increase in voluntary repatriation be expected. The Islamic Republic of Iran as the current chair of OIC, could contribute along with other members of OIC and the United Nations, towards bringing about the improvement of conditions in Afghanistan.

\section{Human rights situation (June- August 2000)}

\section{A. Impact of armed conflict on human rights and violations of international humanitarian law}

38. Civilians continue to bear the brunt of the fighting. In addition to the damage caused by sporadic indiscriminate bombing, a large number of civilians were displaced when they were obliged to abandon their homes and meagre possessions.

39. Around mid-July, reports were received of systematic violations of human rights, including allegations of the summary execution of prisoners in Taliban-held areas in the north of Afghanistan. The Taliban authorities have denied these reports. These allegations call for verification and are a matter to be taken up further with all parties concerned.

40. The Special Rapporteur was able to interview General Ismail Khan and two others who had escaped from a maximum security prison in Kandahar. Before his arrest and detention, General Ismail Khan was the Governor of Herat and had been a commissioned officer in the Royal Afghan Army. He was one of the commanders of the Afghan resistance. He and the two other prisoners described their place of detention in Kandahar as the headquarters of Taliban intelligence known as Istikhbarat, where there were cells which had 
no windows and where they were continuously kept confined except when they were allowed to go out to use toilet facilities. Each of them was kept fettered in chains during their entire period of detention, which extended for some three years. They had no opportunity to send or receive any letters or visits, except that General Ismail Khan was made available for a single interview by the previous Special Rapporteur, Choong-Ayun Paik. It is noteworthy that this was the only time he was taken from the detention centre to a place, said to be the guest house of Mullah Jalil, where he met Mr. Paik in a properly furnished room with two television sets. This was done apparently to give the impression that he was housed in comfortable surroundings. He had not been able to convey to $\mathrm{Mr}$. Paik the harsh conditions of his detention. All three prisoners interviewed spoke of the torture to which those who were brought to that detention centre were subjected. The two interviewees, other than General Ismail Khan, gave harrowing accounts of torture which involved their legs being tied to an iron bar while they were in an upside down position and being beaten with cables. They were able to identify their torturers by name. General Ismail Khan himself did not report being subjected to torture but stated that since his cell was near the place where the intelligence officials conducted their interrogations, he had on many occasions heard the cries of persons who were being subjected to torture. One of the interviewees reported that he had learned that one of the prisoners who had been brought there, Suleiman Zirak, had been taken out and summarily executed.

41. Information was obtained from the interviewees regarding Dr. Ayub, the Superintendent of Shuhada Hospital in Jaghorey (Hazarajat) who has been detained without being charged for over a year and whose release has been repeatedly requested by the Special Rapporteur since May 1999. It was learned that Dr Ayub had spent several months in the Istikhbarat detention centre, before being removed in chains to Sarposa Jail in Kandahar. While in the detention centre he had been asked medically to attend to one of the interviewees when he had been ill.

\section{Landmines}

42. These are in general two categories of landmines: anti-personnel mines, which are designed to kill or maim people, and anti-tank mines which are designed to destroy vehicles but are capable of killing pedestrians and livestock. The key feature of the mines is that they are victim-activated, which accounts for the massive concern about their effects. In all too many conflicts, including that in Afghanistan, most victims have been civilian non-combatants. The indiscriminate effects of these weapons, which remain lethal for decades after a conflict, has led to an international campaign to have them banned. Most nations have now signed a treaty to that effect.

43. The effects of landmines are widespread and horrific. Even simple movement from one place to another becomes fraught with danger, as do activities such as farming, grazing livestock, and collecting water, wood, fodder and other plants. Mines, according to ICRC have the power to deny, by their very presence, the fundamental rights of refugees to return to their native lands. Landmines maim and kill but they also deny people access to farmland, water, pasture, roads and buildings, and kill valuable livestock that is often irreplaceable by the poor rural communities and nomads affected. By destroying or denying access to essential resources, and by adding to rehabilitation costs, landmines hinder economic development. They are an obstacle to post-conflict rehabilitation, to the delivery of aid programmes, to food security, sustainable livelihoods, and the return of refugees and internally displaced persons to their homes. Surveys indicate that some 223 square kilometres of the known mined area is farmland. This represents a loss in production of about 51,000 metric tonnes of cereal products per year, with a local value of over US\$ 13.7 million. Conversely, the farming and grazing land cleared to date has been estimated to contribute around US\$ 40 million annually. For these reasons, the presence of mines is often referred to as a silent war: the effects continue for as long as the mines remain in place. It is estimated that some 70,000 Afghans have been killed or injured by mines and unexploded ordnance in the past decade, causing untold human suffering, and placing a heavy burden on an already marginal health-care system. In 1999, ICRC-supported hospitals alone registered over 2,000 mine injuries, excluding those caused by unexploded ordnance, which is the lowest annual rate since 1979. It is estimated that up to 100 people continue to be maimed or killed every week, although the total number of deaths is difficult to estimate, since most go unreported unless the patient reaches a hospital. Given the types of mines and unexploded ordnance present, rough terrain, poor roads, lack of transport, vast distances and the lack of 
medical facilities, it is considered that some 40 per cènt of victims do not survive. There are estimated to be around 30,000 amputees in Afghanistan, with about 24,000 ( 80 per cent) of those resulting from mine injuries. Since amputees are thought to represent around 60 per cent of surviving mine victims, this would put the number of survivors at around 40,000, one of the highest figures in the world. The need for prosthetic limbs if victims are to recover mobility points to a further problem: that of coping with a lifelong disability. Afghanistan is not a society that is well-equipped to meet the needs of the disabled and, as a result, mine victims are likely to suffer unemployment, loss of self-esteem and clinical depression, for which once again resources are pitifully inadequate. Thus, landmines have significant social consequences, for victims and their families, and for the society as a whole.

44. After more than two decades of war, Afghanistan is one of the most heavily mined countries in the world. In 1996, Kabul was possibly the most heavily mined city in the world, with an injury rate of over 40 per day. Today, as a result of concerted mine action, there are few mines left in Kabul, although, unexploded ordnance continues to be found. Indeed, there is a major problem with unexploded ordnance throughout Afghanistan: wherever fighting has taken place, bombs, mortars, artillery shells, rockets, grenades and other items litter the ground. It is thought that unexploded ordnance may cause even more deaths than mines, especially since poverty has forced many people to attempt to pry open these items to extract and either use or sell the explosive ingredients, or valuable aluminium, copper or brass. To date, 274 square kilometres of battle area has been cleared, however, unexploded ordnance continues to be found, most often by those who fall victim to it. Calculating the scale of Afghanistan's landmine problem is a complex task. According to a recent article:

At least 38 different types of mine have been found in Afghanistan. On occasion, estimates of the number of mines to be found have been put forward: for example, in 1993, the United Nations suggested a total of 10 million mines and items of unexploded ordnance. However, the simple number of mines in a country is a poor measure of the problems they cause, since it tells one nothing about the pattern of their distribution, and the resultant human, social and economic effects. It is more useful to map and count minefields, since a minefield will disrupt normal life irrespective of how many mines it contains, and to count mine-affected communities. Initial data became available in 1993 as a result of the national survey of mines situation in Afghanistan, when 2,353 minefields were identified, occupying 388.75 square kilometres, or 0.06 per cent of Afghanistan's area. $^{\prime}$

Surveys to date have identified over 3,000 minefields that directly affect 1,500 communities and pose a threat to others, including the more than one million nomads who roam the country. By mid-2000, with 211 square kilometres of mined area cleared, it was concluded that 718 square kilometres of land remained affected by mines, with 338 square kilometres demanding highpriority clearance. High-priority areas for clearance were notably to be found in the provinces of Herat $(71.05 \mathrm{sq} \mathrm{km})$, Kandahar $(65.1 \mathrm{sq} \mathrm{km})$, Farah (41.4 sq km), Paktia (28.91 sq km), Zabul (17.52 sq km), Kabul (18.38 sq km), Ghazni (17.4 sq km), Paktika (10.73 sq. $\mathrm{km})$ and Nimruz (7.28 sq km). In Jowzjan, Bamyan and Uruzgan, reportedly no minefields of high priority remained. Clearance remains a substantial task but, fortunately, it is not being significantly complicated by new mine-laying, of which there is evidence only in front-line areas, such as Shamali Valley.

45. On 5 August 2000, gunmen shot and killed seven Afghans working in western Afghanistan for the United Nations-supported mine-action agency that is part of the United Nations mine action programme. The aid workers, all employees of the Organization for Mine Clearance and Afghan Rehabilitation, a mineawareness non-governmental organization, were ambushed and killed on the road between Badghis and Herat provinces. The victims were Saran Wal Shah Poor, Mohammad Azay Malingyar, Abdul Mansoor, Ghulam Destageer, Azizullah Alikozai, Shah Mohammed and Abdul Rahman. Officials of the Taliban militia, which controls 90 per cent of Afghanistan, traded accusations with the opposition over who had carried out the killings. The opposition rejected the charge, saying that the area in which the attack occurred was controlled by the Taliban.

46. A study commissioned by the Office for the Coordination of Humanitarian Affairs on vulnerability and humanitarian impact of Security Council sanctions in Afghanistan ${ }^{2}$ recorded that the population of 
Afghanistan was highly vulnerable and had little capacity to cope with any further economic shocks. The report further noted that, while there was almost no support within Afghanistan for further economic sanctions, an overwhelming majority of those interviewed indicated that an arms embargo would command widespread support and moral authority. As noted by many, United Nations restrictions on the transfer of weapons would avoid the humanitarian contradictions that were associated with economic measures. Moreover, there was a strong consensus among Afghans on the need for the United Nations to upgrade and intensify its political engagement and peacemaking efforts to end the war.

47. The Special Rapporteur has written to the Taliban authorities, requesting permission to visit various cities in order to assess the extent of displacement of civilian populations and damage caused by the resumed fighting and of violations of humanitarian law arising from aerial bombardment and shelling of civilian targets. He would endeavour to visit prisons and the Istikhbarat detention centre in Kandahar, if possible, in order to verify the description of that place and the conditions of detention of the prisoners there. $\mathrm{He}$ would also seek the comments of the Taliban authorities with regard to the allegations of illtreatment and torture made by the interviewees. If those allegations prove to be well-founded, they would constitute violations of international humanitarian law and of humán rights.

\section{B. Impact of Taliban edicts and the existing legal regime on the human rights situation}

48. On 18 July 2000, a Pakistani diplomat, Ibrar Hossain, speaking from the Consulate of Pakistan in Kandahar, stated to Reuters that visiting Pakistani soccer players, who had come to play football as members of the Young Afghan Football Club from Chaman in Pakistan, had been arrested for appearing on the football field in shorts. This had been considered to be a violation of the Islamic dress code enforced by the Taliban movement which forbids the wearing of shorts. The Taliban religious police arrested all but five of the players and shaved their heads. Five of the players managed to escape and seek refuge at the Consulate of Pakistan. The others were subsequently released and all returned home. The Taliban authorities apologized for the occurrence and reported that the person responsible had been removed from his post.

49. Early in July, an edict was issued banning Afghan women from working in non-governmental organizations and United Nations agencies. Since women workers play an important part in relief and other work, this adversely affected the work of the nongovernmental organizations and the United Nations agencies, including WFP, where over 600 women workers were being trained. This training programme was abruptly stopped.

50. The Personal Representative of the SecretaryGeneral raised the issue of the dismissal of female government employees with the Taliban Foreign Minister, who explained that a lack of economic resources had forced the Taliban to eliminate a large number of positions in the civil service and that this had inevitably had a negative impact on women since they were receiving a salary without actually working. This situation had resulted from the fact that, after the Taliban had taken over Kabul, female employees had been able to continue to draw their salaries without being allowed to perform their jobs.

51. On 8 July, Mary MacMakin, an American aid worker aged 71 years, who had worked for over 20 years in Afghanistan running a physiotherapy and rehabilitation centre, was arrested together with seven Afghan female workers on allegations of spying and spreading anti-Taliban propaganda.

52. The United Nations Coordinator for Afghanistan flew to Kabul and Kandahar and took up the issue with the Taliban authorities. In response to representations, Ms. MacMakin and the seven aid workers were released but Ms. MacMakin was directed to leave Afghanistan within 24 hours, which she did. The larger issue of female employment affected by the edict continues to be pursued by the United Nations Coordinator.

53. According to some reports, there has been some relaxation of the strict ban on female education imposed by previous edicts of the Taliban authorities. The strict ban on female education imposed by the Taliban authorities after their takeover of Kabul in 1996 appeared in some measure to be softening. Girls of up to high school age, it was reported, may attend informal schools that are private or funded by international organizations. Early in June, the supreme leader Mullah Omar issued an edict allowing access to 
mosque schools to young boys and girls. In Kabül, considered by the Taliban to be in direst need of "moral reform", the authorities kept a close watch on the officially sanctioned primary and secondary education for girls in mosque schools, and obstructed informal home tutoring. Many female teachers who were sacked from their jobs in the state schools after the Taliban takeover have attempted to teach girls in their homes. - In Kabul, they must register with the Ministry for the Promotion of Virtue and the Prevention of Vice, which maintains a religious police force charged with enforcing the prescribed code of behaviour. In the countryside, far from the eyes of the religious police, families can set up home schooling for girls with the support of village elders and tribal leaders. International non-governmental organizations help to fund some of this informal education.

54. On 8 March, for the very first time in the recent history of Afghanistan, a formal public celebration of International Women's Day was held in Kabul. Seven hundred women of all ages, including former university professors, engineers, teachers, doctors, nurses and school principals attended the celebration. Ten of them were honoured with gifts from the organizers of the celebration - the United Nations system, working in collaboration with the Taliban authorities. The representative of Mullah Omar made a statement at the celebration. Radio Shariah, the official radio station, covered the event, and permission was given to a wide cross section of the international media to cover the event and conduct random interviews with the women present. At the end of the celebration, it was announced that six women prisoners would be released in celebration of the Day.

55. There is an indication that, during a seminar in Kabul of provincial representatives and other officials of the Taliban Ministry of Information and Culture, a proposal was discussed for consideration by the supreme leader of the Taliban to relax the ban on television, so that television may be used to promote Islam. This was the first such proposal made since the edicts of four years earlier, banning television, cinemas and music.

56. In mid-August, the Taliban ordered the United Nations to close down bakeries run by women in Kabul. The bakeries had been selling subsidized bread to 7,000 of the capital's poorest women. Early in July, the Taliban had issued an edict banning foreign agencies from employing any Afghan women outside the health sector. The United Nations had been hoping the bakeries would be exempt. When the Taliban took power in Kabul in 1996, they had banned all women from working. That left begging and charity as the only options left for women who had no male relatives to support them. There are tens of thousands of widows in Kabul alone, a result of two decades of war. The United Nations set up its widow's bakeries specifically to provide for such women. Earlier in the week members of the Taliban religious police had visited some of the bakeries, threatening individuals with beatings if they did not close. A direct order was issued from the Taliban Ministry of Planning that they must shut down but that order was subsequently revoked.

57. The statute on the activities of the United Nations in Afghanistan, promulgated by the Taliban authorities around 15 August 2000, introduces substantial restrictions on the operations of the United Nations and the specialized agencies which provide humanitarian, economic, rehabilitation and development assistance in Afghanistan. Apart from the question of whether the control sought to be established by the statute would be consistent with the obligation of the United Nations and the agencies to conform to the principles of the Charter of the United Nations and in particular their obligation to ensure respect for human rights, these restrictions could impair the capacity of the United Nations and agencies to deliver assistance to communities and needy target groups. This measure could impede the access of the United Nations to all of the people of Afghanistan since such access would apparently require the intermediation of the Taliban authorities.

\section{Concluding observations}

58. In his previous reports, the Special Rapporteur made specific recommendations with regard to human rights violations involving inhuman and degrading punishment, violations of international humanitarian law and, above all, the restrictions imposed on women's rights, which denied women access to employment, education and health facilities. He urged that the edicts, which were inconsistent with the obligations of Afghanistan under the international instruments to which it is party, should be repealed.

59. The relaxation of some of the restrictions referred to above and the apology that followed the incident in which Pakistani football players had their heads 
shaved, indicate the kinds of infringements of human rights that result from the edicts and dress codes enforced by the religious police. This force is composed of young militants who mete out punishment in a rough and ready manner without due process. The Taliban authorities need to understand that their obligations under international human rights instruments cannot be met, and violations cannot be justified, by invoking grounds based on subjective versions of religious or cultural prescriptions, many of which cannot be supported by authoritative religious texts, traditional Afghan practices or the practice of other Muslim countries.

60. The allegations regarding violations of international humanitarian law and the reports of alleged torture and summary execution need to be addressed by the Taliban authorities. The Special Rapporteur would seek the comments of the Taliban authorities on these allegations in the course of his proposed visit to Afghanistan. If such reports prove to be correct, those responsible for summary execution and torture would incur international criminal liability, and the international community must consider appropriate measures to be taken in this regard. The allegations of summary execution and torture warrant further inquiry.

61. A substantial increase in humanitarian assistance is urgently required to meet the survival needs of persons who have been seriously affected by the drought. Increasing international assistance is also needed to meet the needs of the refugees, since largescale repatriation is not feasible for the reasons detailed above.

62. The United Nations and the international community are at present actively focusing on the basic issues to which the Special Rapporteur drew attention in his previous reports, namely, the need for a framework change, through resolute efforts to end the armed conflict, and to move forward with the peace process. This process must be inclusive and involve all segments of the Afghan population, inside and outside the country. The objective would be to rebuild Afghanistan and to restore the country to all of its people. This would only be possible through a negotiated peace and a process of transition aimed at the establishment of a broad-based, multi-ethnic and truly representative government.
63. Such a broad-based government could expect to create conditions of confidence, enabling several million refugees to return to their homeland. Only such a government could be expected to repeal the edicts which result in systematic violations of human rights and to create the conditions under which basic human rights could be guaranteed to the women, men and children of Afghanistan, rights that they are entitled to by virtue of the fact that Afghanistan is party to the main international human rights instruments (including the International Covenant on Civil and Political Rights, the International Covenant on Economic, Social and Cultural Rights, the Convention on the Elimination of All Forms of Discrimination against Women and the Convention against Torture and Other Cruel, Inhuman or Degrading Treatment or Punishment).

64. More than 10 years after the Geneva Accords, the United Nations and the international community should not be content with half-measures and inadequate steps which will prolong the agony of the Afghan people who continue to be victims of a prolonged conflict that is supported and promoted by external forces. They have too long been denied the protection from external interference assured them by the Geneva Accords and repeatedly urged by the Security Council, and protection of their human rights as guaranteed by international instruments.

\section{Notes}

'William Maley, "Mine action in Afghanistan", in Refuge, vol. 17, No. 4 (Toronto, Canada, Centre for Refugee Studies, York University, October 1998).

2 Under preparation. For a summary, see $<$ www.reliefweb.int $>$, "By country". 


\section{Letter dated 26 April 2000 from the Special Rapporteur of the Commission on Human Rights on the situation of human rights in Afghanistan addressed to the President of the Islamic State of Afghanistan}

I am extremely concerned that, despite repeated calls for a ceasefire by the Security Council and the General Assembly, reports are being received that preparations are under way for a military offensive by both sides involved in the armed conflict in Afghanistan. Armed conflicts inevitably lead to grave violations of human rights and international humanitarian law and inflict enormous suffering on civilians, in particular women and children. Such violations also give rise to international criminal responsibility on the part of those responsible for such violations and add to further instability in the area.

You will recall that in the correspondence I addressed to both sides in 1999, I had appealed for restraint and urged them to avoid violations of human rights and humanitarian law and in the infliction of suffering on civilians, in particular women and children.

The Secretary-General of the United Nations has been gravely concerned that civilians are still being deliberately targeted in different front-line areas in Afghanistan. He has deplored the indiscriminate bombing in the Panjshir Valley on 14 February 2000, which resulted in the death of eight civilians and has had terrible repercussions for civilians and internally displaced persons in the area.

The President of the Security Council in his statement of 7 April 2000 expressed deep concern at the reports that both parties to the conflict in Afghanistan are preparing for renewed large-scale fighting, and recalled the Council's repeated demands that the Afghan parties cease fighting.

The Commission on Human Rights, in its resolution adopted on 18 April 2000 on the situation of human rights in Afghanistan, strongly condemned the mass killings and systematic human rights violations against civilians and persons deprived of their liberty for reasons related to the armed conflict. The Commission urged all the Afghan parties to cease hostilities immediately and to reaffirm publicly their commitment to international human rights and principles and to recognize, protect and promote all human rights and fundamental freedoms.

I appeal to both sides in Afghanistan to be aware of the above concerns and to refrain from resumption of armed conflict and in any event to avoid the types of violations that have characterized past offensives. I once again appeal to you and others in positions of authority and responsibility to take all necessary measures to safeguard the life and well-being of civilians and to pursue a resolution of the conflict by peaceful means.

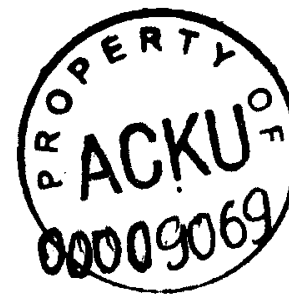

(Signed) Kamal Hossain Special Rapporteur of the Commission on Human Rights on the situation of human rights in Afghanistan 